\title{
Translating law in the digital age. Translation problems or matters of legal interpretation?
}

\begin{abstract}
This paper focuses on the issue of how translations of legal contents from webpages are received or interpreted within the target legal system. Our hypothesis is that software developers and companies operating in the digital market and offering multilingual contents, which were created originally in English and translated into Spanish, are not only setting the standards for drafting legal texts for publication on the internet but also coining (or even imposing) equivalents that do not always take into consideration the target legal culture. Indeed, the major IT companies, with their policy of making contracts freely available for downloading, and with the valuable linguistic resources that they produce and distribute, are not only meeting the requirement of keeping their clients informed but are also becoming the new authority on IT terminology and legal translation. The legal texts produced by these companies constitute a multilingual digital corpus of important value for translators and localizers. We assume that translation techniques and equivalences used in the target text satisfy the legal requirements of the consumer's country of residence and are therefore adapted in order to be fully interpreted according to Spanish law. However this is often not the case as is discussed here.
\end{abstract}

Keywords: legal translation, standardisation, functional approaches, localisation, target-text oriented approaches.

\section{Introduction}

In recent years internet has become an extremely useful multilingual corpus for translators. The need for companies to communicate within a global context has resulted in the production of a large body of multilingual digital documents, many of which are of a legal nature. Company websites, for instance, contain licences and terms of use, service contracts, privacy rules, corporate documents, etc., all couched in legal phraseology and with their corresponding translations into the languages of the potential clients that they target. Millions of translated words and their respective contexts, which 
in the past could only be accumulated over many years of professional activity, are thus placed at the translator's disposal.

The value of this multilingual corpus is further increased by the fact that it has been constructed from texts that have been published, subscribed to and accepted on internet - which makes them freely accessible to all users. This ease of access to source texts (ST) and their respective translations is precisely what enables them, on the one hand, to be used as parallel texts for new translations and, on the other, as raw material with which to feed multilingual corpus-based search tools. The process of documentation for translation purposes is now much easier than before since search engines provide ready-made, statistically-validated solutions for translation problems. These, however, do not necessarily guarantee the quality of the translation product. Indeed, it has become increasingly difficult for both expert and novice translators to justify not following the "google rule", i.e. adopting the most commonly-used translation, when making their translation decisions. Novice translators typically adopt this method as their main criterion when validating equivalents. Expert translators who, according to Pym (2008), have a natural aversion to risk-taking, often rely on this method too, in particular when dealing with specialist texts. We assume that translation techniques and equivalences should vary to ensure that terms used in the target text satisfy the legal requirements of consumer's country of residence.

Much of the legal content on the Web is in the form of general contract terms and conditions, for instance the provisions of the Terms of use of any Web page, that are in highly- standardised legal formats, which makes it easy to use-just by cutting and pasting - in other contexts. The multilingual, digital corpus of translated texts, thanks to its ease of access, could eventually set the standards for translating other types of contracts into Spanish, since this is the pair of languages we have analyzed, but also for legal translation as a whole. If, according to Mayoral (2004, p. 63), all 
participants in the translation act influence the way in which a text is translated, in this case the number of participants intervening in the translation act may be reduced to a single individual who creates the source text, sets the translation brief and, moreover, determines the translation method used.

\section{Translating Law}

The legal translator, who has to translate between two legal systems in which finding an absolute equivalent (a near-equivalent according to Sarcevic, 1988, p. 44) is the exception to the rule, is forced to find a balance between a certain degree of terminological creativity (through loanwords, calques, explanatory paraphrase or neologisms) and the use of functional equivalents that may fulfil the requirement of communicating the message but risks losing sight of the ST legal culture. This must be done in real time with each new translation, avoiding in the process the many pitfalls that experts in translation theory warn of. Both translator trainers and researchers emphasise that the translation of legal institutions must be the object of contrastive study on a case-by-case basis. It has even been claimed that the difficulty of legal translation is the best safeguard for the profession as a whole: "it seems justifiable to say that legal translation is in practice as well as in theory is [sic] a secure profession demanding special technical knowledge because of its complexity" (Galdia 2003, 4).

The almost total absence of equivalence due to conceptual incongruity (Gémar 1998, 6; Sarcevic, $1985,127)$ could, however, lead many to defend an extreme "anything goes" policy, provided that target readers are duly warned that the translation they are being offered is for information purposes only. This takes us back to practices that are clearly oriented towards the source culture. It is true that in most cases the translation of contracts is for information purposes only. The question is, though, whether, in the age of globalisation, the frequency of use of an equivalent can be adopted as the main 
criterion for deciding that a translation for information purposes is comprehensible in the target language. As always, the answer will depend on the translation brief. However, in the recentlycreated field of translation of the legal content of websites, especially technology law contracts, the need for and use of terms in the source language and their corresponding target-language equivalents occurs immediately as the drafting, translation and localization of the text take place almost simultaneously. The situation is similar to translation in bilingual and multilingual jurisdictions in which, in the words of Sarcevic (2000, p.1), 'the success of an authenticated translation depends on its interpretation and application in practice', i.e. its application by courts in the receiving jurisdiction.

In the translation of legal content on websites, and of technology law contracts, the target text (TT) does not have the status of an authentic text but rather of a text that is open to interpretation under the applicable law of the target legal system. Although in IT terminology the creation or coining of a new term in English leads almost automatically to its incorporation into other languages in the form of loans or calques (recent additions to the Diccionario de la lengua española (DRAE) include blog, chat, SMS, tableta, etc.), in the case of legal terminology the reception of translated texts has its "implications for the decision-making process of translators" (Sarcevic, 2000, 1). Therefore in line with Sarcevic's theory, translations of legal content on websites should take into account the law that is applicable in each case.

We would agree with the statement that the fundamental aim of legal translation is to communicate a message generated within another legal culture. In practice, though, this means that translators often turn into seekers of previously-translated terms used in the receiving community (usually legal practitioners) to ensure that their translation really does achieve that communicative goal. Until recent times, translators relied on the term bases and corpora provided by international organisations, international law courts and bilingual jurisdictions (as is the case with common law in Canadian French) when searching for a precise translation of a concept that does not exist in the target culture. 
This resulted in the production of what Monzó (2002) has termed a "transgenre". In other words, translations could always be identified as such ("mere translations" following Sarcevic 2000, p.1), and so could easily be differentiated from a text that had been created originally in a particular language. Thus, the degree of acceptability of a specific translation procedure was largely determined by the prestige of the documentation source. Indeed, despite what some authors seem to claim (Weston, 1991, p. 23), functional equivalents in legal translation may not always be the best

option, since they can be misleading and inappropriate due to conceptual incongruity (Sarcevic, 2000, p. 7). On the other hand, neologisms should also be used with caution since there is "the risk that it [the neologism] could sometimes only be understood by the creator of the new term" (Kieffer, 1995, p. 229). Experts therefore recommend the use of neologisms be accompanied by a translator's note in order to fully clarify the source text concept (Monjean-Decaudin, 2012, p. 387). Occasionally, lexical expansion may be used, as in the case of a culturally marked term that is unknown in the target culture (Sarcevic, 2000, p. 7). Translators' approach to terminological renewal in legal translation should be carried out with caution as indicated by De Groot (2008, p. 6):

If one can assume that some users of the target text already encountered at some point or another these neologisms chosen by others in publications to express the terms in question from the source language legal system, one should seriously consider adopting the choice of earlier translators. One should be aware that choosing one's own neologisms could lead to confusion. Naturally, the likelihood of confusion is dependent on the notoriety of the earlier publication, in which a particular neologism was introduced.

\subsection{Translating law in the digital age}

Our hypothesis is that software developers use their dominant market position as a platform for consolidating legal practices in general (for example, the inclusion of software among the works that are protected by intellectual property laws) and contracting practices in particular (licences, legal 
warnings and general conditions of use, among others), which eventually puts them in a position to set the standard for drafting legal texts for publication on Internet, both in the source language and the different target languages. Indeed, the major IT companies, with their policy of making contracts freely available for downloading, and with the valuable linguistic resources that they produce and distribute, are not only meeting the requirement of keeping their clients informed but are also becoming the new authorities on terminology in legal translation in general since the texts produced effectively constitute a multilingual digital corpus. Decisions made for reasons of market positioning feed into the statistical results obtained through search engines and end up setting translation models or, in other words, the "google rule". It is true that translators remain in charge of their own translation decisions, but it is no less true that the viral spread and lightning-fast uptake of equivalents can lead them to discard other translation procedures or equivalents that they fear will have less communicative impact on target readers, who are bound to be users of search engines as we show in Figure 1.

Figure 1.- Virtual circle of searching for legal terms on the Internet

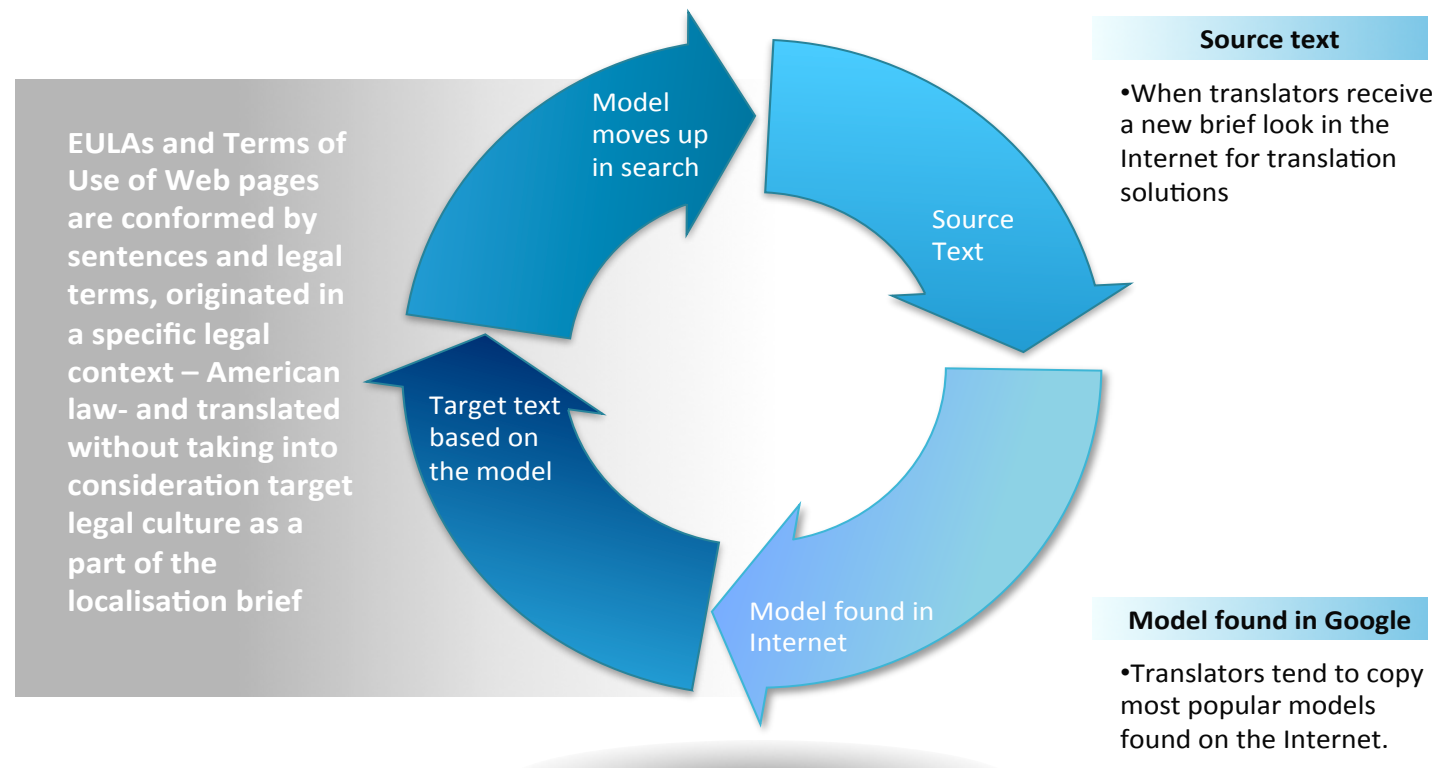

The existence of this multilingual digital corpus alongside the increasing popularity of high-quality bilingual text alignment tools (Linguee ${ }^{1}, 2$ lingual $^{2}$, etc.), online bilingual dictionaries that also offer 
aligned corpora (e.g. Reverso dictionary ${ }^{3}$ ) and other extremely advanced corpus tools (Webitext, ${ }^{4}$ Glosbe ${ }^{5}$, etc.) may compel translators to simply select terms and phrases that, having been translated previously, may be considered as validated ${ }^{6}$. As a result, as we have seen, the choice of one or another equivalent is often justified by its having been previously used by other translators and the receiving community. When translators confirm the existence of an equivalent in this way they consider their choices validated and assume the translation to be acceptable.

Moreover, many translations available on Internet are generated through automatic or semiautomatic localisation processes that hinge on reusability, a concept derived from software engineering. This concept can easily be applied, through localisation, to the field of translation reuse. Indeed,

Translation reuse works as a cost-saving approach because the assumption is that the document corpus of most organizations (or at least that part of it relevant to globalization) grows only incrementally, by adding limited amounts of new linguistic material to larger bodies of existing linguistic material (Shreve, 2006, p. 310).

\subsection{The translation of terms and conditions of digital products}

In recent times companies have been able to speed up their sales capacity through the massive use of online forms, which allows them to execute contracts rapidly, efficiently and, above all, at very little cost. Indeed, the volume of transactions conducted online has now reached the point of revolutionising the business model of certain sectors. Online travel agencies, to cite just one example, have almost done away with the face-to-face model. This phenomenon has accelerated the creation of standard clauses to be used in different contracting situations. These are the boilerplate clauses or 
terms and conditions of contracts, made up of ready-to-use clauses, drafted by one of the parties with the aim of inserting them in a wide range of contracts. In the words of Díez-Picazo (2007, p. 437):

... in the modern economy, much of what we have termed 'mass contracting' takes place under uniform conditions that are pre-established by a company or group of companies, which imposes them on potential clients every time one of these contracts is executed, with no possibility of modification or even discussion ${ }^{7}$.

Among other characteristics, these clauses, available nowadays on Internet, typically consist on highly interchangeable legal content that can appear in contracts in a variety of different fields, such as construction, transport, distribution, intellectual property, international sales of goods, ecommerce, etc. Indeed, in some contracts (end-user licence agreements, for instance) the so-called boilerplate clauses account for as much as 60 to 75 per cent of the text ${ }^{8}$. These clauses were originally drafted in English and then translated or re-written in Spanish, but they retain many conceptual features that reflect their origin in a different legal culture. This confirms the fact that we are dealing with hybrid legal content as described in previous studies (see Bestué, 2009, p.105; 2013, p. 152). It is this very content that can lead to problems of interpretation.

In most cases contents are not presented as translations. Produced by global companies that conduct their business almost exclusively on the Internet, they appear to have been drafted as originals. This is because the system identifies the users' countries of residence prior to diverting them to an interface in which the contents are presented in the user's own language. The influence of translation is, however, palpable due to the presence of terms that, when analysed from the perspective of Spanish law, generate an issue of legal interpretation. An example of this can be seen in the following extract from the terms of service of a well-known search engine ${ }^{9}$ : 
Podemos suspender o cancelar nuestros Servicios si no cumples con nuestras políticas o condiciones o si consideramos que tu conducta puede ser malintencionada.

In this sentence we encounter a problem with the term conducta malintencionada. In Spanish law, the concept of conducta malintencionada (malicious conduct) has not been developed under civil law and it can be defined as an unknown or non-existent term. Moreover, as evidenced by a Spanish court, in the recent Ryanair case ${ }^{10}$ on consumer law, terms and conditions of online services must be interpreted in accordance with national law. Concepts that are unknown to Spanish law must therefore be subject to interpretation under the rules of legal hermeneutics for contracts ${ }^{11}$. According to these hermeneutic rules clauses that are clearly worded are to be interpreted literally, but where wording is not clear, as in this case, the obvious intent of the contracting parties must be resorted to ${ }^{12}$. The search engine's terms of service include a clause of submission to the laws of California, and although no reference is made to the original English version for the purposes of interpretation, when determining the company's intent it may concluded that the term conducta malintencionada is a translation of the English word "misconduct", which may be described as harmful intent or conduct. Logical, systematic interpretation leads us to conclude that harmful intent in the user's behaviour must be examined solely in relation to the contract itself and the service provided. Any other harmful conduct, unrelated to the service provided, must therefore be excluded. Furthermore, any harmful conduct in relation to the contract is already covered by other clauses on breach of contract, whether fraudulent or negligent. Thus, from the definition of the English word "misconduct", our interpretation of this clause should be in terms of the need to cover any responsibility on the part of the company offering the service when the user uses it correctly but with the intent to cause harm to a third party (by copying content, piracy, infringing image and privacy rights, etc.). This serves to establish the legal framework for using the service and allows the company to terminate it if it is used in ways that can be harmful to third parties. We can conclude, therefore, that this clause allows 
the company to fulfil its responsibilities under Spanish law as an information society service $\operatorname{provider}^{13}$.

However, given the way in which the clause is worded, it can only clearly and directly be interpreted if reference to the English source text is made. This could leave the user with no recourse if the provider unilaterally suspends the service. Moreover, in terms of its legal interpretation, this clause may be rendered null and void if the person receiving the service is a consumer. According to Spanish legislation on consumer protection ${ }^{14}$, clauses that do not respect the principles of reciprocity are deemed to be unfair, i.e. when one party can terminate the contract at its own discretion, but the other, the consumer, cannot. In any case, when a breach of contract by a user is contested it should always be resolved in a court of law.

In order to shed some light on the concept involved we will now examine this case from a translation perspective. We therefore consider the previous Spanish example as a TT in a translation brief. In the English version of the Terms of Service quoted, the condition is expressed as follows:

"We may suspend or stop providing our Services to you if you do not comply with our terms or policies or if we are investigating suspected misconduct".

Black's Law Dictionary defines misconduct as "unlawful or improper behavior". In Spanish, however, the term mala intención or conducta malintencionada is much broader, referring to the person's will or mood, and therefore to a state of mind, which does not necessarily lead to illegal or incorrect behaviour. Correct expressions in Spanish in this context could be, for example, conducta irregular, conducta fraudulenta, or conducta indebida and perhaps, though with less certainty, mala conducta.

We assume that this sentence could refer to cases in which the service is used correctly but with the intention of causing harm to third parties. Therefore, there is no moral judgement (which could be 
alluded to by the expression mala intención) but rather legal characterisations deduced from the user's conduct regarding the purposes of the service.

As we show in Table 1 reception of a TT has a clear impact in the interpretation of the text, since hermeneutic rules vary from one country to another. As a result, translation oriented to the TT legal culture ends up in a more efficient process of production of multilingual legal texts (or translations), enhancing the communication act in the interests of legal precision and clarity, which in turn has a direct impact in the survival of the contract when disputes between parties may arise.

\section{Legal perspective}

\begin{tabular}{|c|}
\hline Legal content \\
\hline Legal interpretation \\
\hline Not literal sense \\
\hline Intention of the parties \\
\hline Back translation \\
\hline Strict interpretation \\
when consumers involved \\
\hline Possible unfair clause \\
\hline
\end{tabular}

\section{Translation perspective}

\begin{tabular}{|c|}
\hline Legal ST \\
\hline Searching for meaning in the \\
\hline SC \\
\hline $\begin{array}{c}\text { Searching for functional } \\
\text { equivalent in TC }\end{array}$ \\
\hline TT adapted into TC \\
\hline Legal interpretation of TT \\
\hline Literal sense \\
\hline
\end{tabular}

\section{Valid clause}

Table 1.- Text as object of legal interpretation versus legal translation that we consider to be mainly the product of translation. However, in application of the rules on interpretation, such as the contra proferentem rule, in case of doubt the court must rule against the draftsman. Courts, on the other hand, seem to declare unfair clauses null and void when they allow one of the parties to terminate the contract unilaterally. Similar resolutions have been applied in the insurance and travel contracts sector in particular, and, to a lesser degree, in the banking sector (e.g. judgement 401//2010, 1 July 2010 of the Spanish Supreme Court) but we are unaware of any caselaw in the context of digital content of web pages, which sees practically no consumer litigation. 
Translation can be seen to leave its mark not only on conceptual but also on the syntactic features of web pages in Spanish. Examples in Table 2 have been taken from pages that are not presented as translations and, moreover, belong to companies based in Spain.

\begin{tabular}{|c|c|}
\hline $\begin{array}{l}\text { Phrases that seem to show the influence of } \\
\text { English on syntactic structures }\end{array}$ & $\begin{array}{l}\text { More natural syntactic structures in } \\
\text { Spanish }\end{array}$ \\
\hline $\begin{array}{l}\text { - En relación con pedidos especiales, por } \\
\text { ejemplo, instalaciones para discapacitados, } \\
\text { XXX se esfuerza diariamente por reducir o } \\
\text { minimizar los efectos de transacciones } \\
\text { fraudulentas con tarjetas bancarias. } \\
\text { - Todo el contenido de este sitio Web } \\
\text { (incluyendo, a título informativo y no } \\
\text { limitativo, marcas comerciales, textos, } \\
\text { gráficos... } \\
\text { Si por causas de Fuerza Mayor (incluyendo, } \\
\text { con carácter enunciativo pero no } \\
\text { limitativo, desórdenes políticos, económicos } \\
\text { u otras situaciones de inestabilidad que } \\
\text { afecten a la seguridad) }\end{array}$ & $\begin{array}{l}\text { - En relación con solicitudes especiales, por } \\
\text { ejemplo, instalaciones para personas con } \\
\text { discapacidades }{ }^{1} \\
\text { XXX hará todo lo posible para/hará todos los } \\
\text { esfuerzos posibles para/ no escatima los } \\
\text { esfuerzos para reducir o minimizar los } \\
\text { efectos de transacciones fraudulentas con } \\
\text { tarjetas bancarias... } \\
\text { - Todo el contenido de este sitio Web } \\
\text { (incluídas, sus marcas comerciales, textos y } \\
\text { gráficos, entre otros...) } \\
\text { - Si por causas de fuerza mayor (incluídas } \\
\text { entre otras, las provocadas por desórdenes } \\
\text { políticos, económicos u otras situaciones de } \\
\text { inestabilidad que afecten a la seguridad) }\end{array}$ \\
\hline
\end{tabular}

Table 2. Examples of syntactic features in Spanish influenced by English.

These are the kinds of syntactic calques that appear when relying on English models for content and wording: perhaps not incorrect grammatically but which certainly sound strange in the target language. Thus, in English, for example, we find a stereotyped formula that leaves an enumeration open, namely the expressions "including but not limited to" and "including without limitation". This formula is used frequently since the courts have defined its scope of interpretation clearly and lawyers feel safe when including it in contracts. In cases of exclusions for indirect damages, for instance, the courts have specified that 'the use of the phrase 'including but not limited to' is a strong pointer that the specified heads of loss are but examples of the excluded indirect loss ${ }^{15}$."

\section{The need for different translation procedures when consumers are involved.}

\footnotetext{
${ }^{1}$ Although "persona discapacitada" has been accepted as a neologism in the DRAE recent legislation and trends in language use would suggest adopting a less pejorative term such as "persona con discapacidad".

${ }^{2}$ In this case there is an improper use of the gerund and an unnecessary, unidiomatic explicitation, since "a titulo informativo y no limitativo" can be replaced, among others, by expressions that indicate an open enumeration.
} 
An important characteristic of terms and conditions is that their subscribers, who have no possibility of negotiating conditions individually, are usually consumers. In most legal systems, consumers are given special protection regarding contracts, and it is precisely because they have no negotiating power that companies are obliged to use "plain, intelligible language" in order to avoid nonenforceability of a clause in the event of a dispute ${ }^{16}$.

Translation procedures and equivalences should vary to ensure that terms used satisfy the legal requirements of consumer's country of residence. In this article, we use the same concept of consumer as that reflected in EU legislation: “"consumer' means a natural person who, in transactions covered by this Directive, is acting for purposes which can be regarded as outside his trade or profession ${ }^{17}$. Use given to the product or service is what therefore determines whether a contract will be included in the category of consumer law or not.

However, neither licence contracts nor conditions of use for software usually make any mention of the actual use to which the software is to be put. Companies draft clauses in such a way as to cover both personal and professional use. Occasionally the contract will specify that the product be meant only for personal use, not commercial use, in which case clauses look something like this:

Subject to your agreement to and continuing compliance with this Agreement and the Terms of Service, we hereby grant to you a nonexclusive, nontransferable, revocable, limited right and license to: (i) install the Software solely for your personal, non-commercial use.

In this clause, the licensor limits the exploitation rights to the private sphere which means that commercial or professional exploitation might require another licence or granting of rights (subject to further payments by the licensee) or that the product is protected by a patent (often subject to payment of royalties in the case of professional uses). The products that usually include these kinds of limitations are games, videos, images, music, etc., which, by their very nature, may have components that are covered by one or more patents. Websites or pages, on the other hand, usually have a personal-use-only clause that expressly forbids their use for commercial or similar purposes. 
Thus, in most digital legal content other than in the above cases, no distinction is made between individual consumer use and professional use. In licences for using software, for example, licensees are defined as end-users since it is the very nature of the software itself that tells us if it can be exploited commercially or used in various devices simultaneously. In fact, developers usually place limits on software use (for example, the number of devices authorised to use a particular programme) but this does not automatically imply professional use only. In general, in the case of licences the wording is the same whether the product is for personal use (a poem for school, a shopping list, etc.) or professional use (a literary work, a contract, a report etc.). This has no practical implications for the ST as the clauses have been written in English in line with the legal systems of Common Law countries. In translation, however, whether applying functionalist theories (Nord, 1997) or focusing on the requirements of the governing law of the TT (Sarcevic, 2000), different procedures must be adopted when the end-user is a consumer and as such is protected by strict rules of interpretation.

In our opinion, consumer law's demand for “plain, intelligible language" when drafting legal content aimed at Spanish consumers should be interpreted, firstly, as an obligation to translate legal contents into the official language of the country. Secondly, it should be seen to impose criteria of quality in translation, which, at the very least, should be natural and comprehensible to a native speaker of the country concerned, or in other words, free of jargon that is not needed in the target language. And finally, it should be possible to interpret the TT under the law of the target culture, without having to resort to other legal systems to interpret non-existent terms or terms with no clear content in Spanish law.

\section{Practical examples of legal translation in websites on the Internet}

Examples are given in this section of some texts and translations of boilerplate clauses (also known as miscellaneous provisions, or terms and conditions) taken directly from company websites on the Internet. Some texts were presented as translations, others as different original language versions of 
the company's webpage. All examples used were written in English. They were subsequently aligned with their corresponding translations into Spanish with a view to ascertaining their validity in different translation contexts. Attention is focused in particular on determining whether or not the translations conform to Spanish law. As we have already seen, translations that disregard Spanish law result in poorly resolved translation problems that may lead to legal interpretation issues and a negative impact on the validity of clauses when the receivers of the translation are consumers.

Source Text: Because the software is licensed, not sold, the company reserves all rights (such as rights under intellectual property laws) not expressly granted in this agreement.

Target Text: Debido a que el software es licenciado y no vendido, la empresa se reserva todos los derechos (tales como derechos bajo leyes de propiedad intelectual) no concedidos expresamente en este contrato.

In the previous example "intellectual property law" and leyes de propiedad intelectual are lexical translations that don't take into consideration the TT legal system. Therefore we recommend an alternative TT adapted to the TT legal system.

Adapted T.T: Debido a que el programa es licenciado y no vendido, la empresa se reserva todos los derechos (tales como derechos reconocidos por la legislación de propiedad industrial e intelectual) que no se otorguen expresamente en este contrato.

In Spanish law propiedad intelectual is a near-synonym of author's right, being defined as a series of rights that correspond to authors (including also artists, producers, broadcasters, etc.) with regard to the works they have created. It does not include such concepts as patents, brands, etc. which, in contrast, are included in the English concept of intellectual property. In fact, intellectual property is any product of the human intellect that the law protects from unauthorized use by others. The lexical translation of this concept therefore restricts the scope of the term when used in the target legal culture. In this case a translation for information purposes should include the two terms needed to 
fully express the ST concept in Spain, if the translation is aimed at Spanish consumers. In an international context, however, the term propiedad intelectual encompasses both industrial and intellectual property.

Source Text: Dispute means any dispute, action, or other controversy between you and PROVIDER concerning the software (including its price) or this agreement, whether in contract, warranty, tort, statute, regulation, ordinance, or any other legal or equitable basis. "Dispute" will be given the broadest possible meaning allowable under law.

Translated Text: Disputa es cualquier disputa, acción o controversia entre usted y el proveedor con relación al software (incluido su precio) o este contrato, ya sea sobre una base contractual, de garantía, de responsabilidad extracontractual, estatutaria, reglamentaria de ordenanza o cualquier otra base legal o equitativa. "Disputa” tendrá el significado más amplio posible permitido por la ley.

Spanish law does not contemplate the dichotomy legal and equitable basis, which differentiates common law and equity law. In an informational context we could resort to one of the translation procedures proposed by dictionaries, such as descriptive paraphrase, but when Spanish readers are concerned this could induce errors with regard to the concept of equidad (equity) in Spanish, which bears no relation to the term in English. Furthermore, in this context no problem of interpretation arises since the enumeration ends with a concept that encompasses all the others. We therefore recommend an open formulation cualquier otra base legal (any other legal basis) since its broad meaning covers any source of law. Another lexical translation that should to be avoided is the translation of "statute" by estatutaria (a specific kind of act or rule under Spanish law) since its functional equivalent under Spanish law is legislativa.

We propose a T.T. oriented to TT legal culture and therefore with an informative purpose for target culture readers: 
Por "controversia" se entiende cualquier controversia, acción o conflicto entre usted y el proveedor con relación al programa (incluido su precio) o este contrato, y con independencia de que su fundamento sea de naturaleza legislativa o contractual, que sea derivado del incumplimiento de la garantía o de un supuesto de responsabilidad extracontractual, o que se sustente en cualquier otra base legal. "Controversia" tendrá el significado más amplio posible permitido por la ley.

The same problem, lexical translation without taking into consideration its reception in the TT legal system, is shown below:

Source Text: If this contract is with Microsoft Corporation, then claims for breach of this contract will be subject to the laws of the State of Washington, without reference to conflict of laws principles.

Translated Text: Si este contrato se celebra con Microsoft Corporation, las reclamaciones por incumplimiento de este contrato estarán sujetas a las leyes del Estado de Washington, sin referencia a conflictos de preceptos de ley.

This clause specifically addresses the issue of the parties' choice of law. International contracts usually include a clause referring to the governing law in order to bring legal certainty to the rights and obligations arising from the contract. When both parties are professionals, parties may agree to submit the contract to the legal system of the country of their choice. As De Miguel $(2012,245)$ has pointed out

...establishing the governing law in an international contract through an expressed term in its provisions is fundamental, since it is thereby possible to fix the legal system which will provide the criteria used for interpreting the contract, the implied terms of the contract, and establish the limits of the parties' freedom of choice with regard to the dispositions included in the contract.

In the absence of this kind of clause the governing law of the contract will be determined by the conflict of law rules of the country in which disputes are presented. Many international contracts 
select English law as the governing law because of the advantages it presents with regard to its highly developed case law, and its less restricting statutory regulation, which allows parties to fix the contents of the bargain by drafting precise, detailed provisions.

In some cases, to ensure equal bargaining power, the parties may decide to forego selection of the governing law of either one of their countries in preference of a neutral legislation. When several bodies of law exist in a country, such as in the United States, the governing law selected is usually that of a specific State. Fixing the governing law implies that the substantive rules of the state or country involved will regulate the interpretation of the contract. Consequently, neither the conflict of laws principles nor the renvoi rules of that state or country should apply. For this reason, in order to ensure a clear interpretation of the contents of the contract, a governing law clause is included to expressly state that the private international law of the country does not apply. According to De Miguel $(2012,250)$ this clause is merely a clarification to stress the fact that ...the choice of the law of the contract must be interpreted in terms of the substantive rules of a country without taking into account any reference made to a different legal system in the conflict of law principles of that country.

In the EU, the law applicable to contractual obligations is regulated by Regulation (EC) $N^{0} 593 / 2008$ of the European Parliament and of the Council of 17 June 2008 (Rome I). Freedom to select the governing law, however, is restricted in the case of consumer law when the consumer is in a situation of inferiority in respect of the professional.

In the example given above, the term conflict of laws means the principles of choice of law and is used as a synonym of private international law. It means the body of jurisprudence that undertakes to reconcile differences on applicable law or to decide the law governing in a given situation. The Roma I regulation excludes renvoi therefore reference to a domestic law is a direct reference to the 
substantive rules of that law. That way, by preventing the application of the designated country`s conflict of laws principles, a court may not refer back to the law of a different country. Considering conflict of law principles as a specialised term oblige translators to recover its notional content and to select a translation that is properly couched in legal Spanish as is the case in the below proposition of TT adapted to target legal system: Si este contrato se celebra con Microsoft, las reclamaciones por incumplimiento de este contrato estarán sujetas a las leyes del Estado de Washington, sin que sean de aplicación sus normas sobre conflictos de leyes.

\section{Conclusions}

The aim of this article was to analyze the impact of reception of legal translations in the target legal system. In particular, within the field of technology law and the legal contents of webpages, translations or legal contents of webpages written in Spanish "as originals" should conform to the dictates of Spanish law when the receiver or end-user is a consumer. European consumer law provides a system of protection for consumers since it is assumed that they are at disadvantage vis-avis professionals regarding the level of information they possess and their bargaining power. This is particularly clear when consumers are forced to abide by a contract in which the influence of a foreign legal system is apparent. Much of this influence is exercised by the common law culture from which the contractual forms are derived but it may also be the result of a translation or an original which has been created using search engines and other web tools as the main documentation resources. These translations serve to coin and spread equivalent legal terms in other languages but don't necessarily take into consideration their impact in the target legal culture. The examples given in this article show how a TT that is not oriented towards the TT legal culture may in fact compromise the information load of the text. Translation procedures that take into account the reception of the text in the target legal system may involve a greater effort on the part of the translator to ascertain and comprehend the concepts and mechanisms of the law, but legal certainty, 
as we have seen, is improved and therefore survival of the provisions of a given contract in the target legal system is better guaranteed. 


\section{References}

Bestué. C. (2009). Traducir los daños sin efectos colaterales: análisis comparado del derecho de daños [Translating damages without collateral effects: a comparative analysis of damages]. Hermeneus, 11, 81-107.

Bestué, C. (2013). Los contratos traducidos: La traducción de los contratos de licencia de uso de programas de ordenador [Translated contracts: translation of software license agrements]. Valencia:Tirant lo Blanch

De Groot, R. and van Laer, Conrad. 2008. "The Quality of Legal Dictionaries: An Assessment" (October 21, 2008). Available at SSRN: http://ssrn.com/abstract $=1287603$ or http://dx.doi.org/10.2139/ssrn.1287603

De Miguel, P.A. (2012). Cláusulas de elección del Derecho aplicable [Choice of law clauses]. In Sixto A. Sánchez Lorenzo (coord.), Cláusulas en los contratos internacionales: Redacción y análisis. (pp. 243-268). Barcelona: Atelier libros jurídicos.

Díez-Picazo, Luis. 2007. Fundamentos del Derecho Civil Patrimonial I. Introducción. Teoría del Contrato, Sixth ed. Cízur Menor (Navarra): Thomson, Civitas.

Galdia, Marcus. 2003. "Comparative law and legal translation”. The European Legal Forum 1: 1 - 4.

Gémar, Jean Claude. 1998. "Les enjeux de la traduction juridique. Principes et nuances". Traduction de textes juridiques: problèmes et méthodes, Equivalences 98, Séminaire ASTTI. http://www.tradulex.com/Bern1998/Gemar.pdf

Mayoral. Roberto. 1997-98. "La traducción especializada como operación de documentación”. Sendebar, 8/9: 137-154. 
Mayoral, Roberto. 2004. "Lenguajes de especialidad y traducción especializada. La traducción Jurídica”. In Manual de documentación y terminología para la traducción especializada, edited by Consuelo GONZALO and Valentín GARCÍA YEBRA Madrid: Arco/Libros. 49-71.

Melero, M., Badia, T., and Moreno, A. 2012. La lengua española en la era digital. Serie de Libros Blancos Meta-net. Heildeberg: Springer. Available at http://www.meta-net.eu/whitepapers/ebook/spanish.pdf

Monjean-Decaudin, S. (2012). La traduction du droit dans la procédure judiciaire : Contribution à l'étude de la linguistique juridique. [Translation of law in the Judicial Process : A contribution to the study of legal linguistics]. Paris: Dalloz.

Nord, Christiane. 1997. Translating as a purposeful activity. Functionalist approaches explained. Manchester: St. Jerome Publishing.

Pym, Anthony. 2008. "On Toury's laws of how translators translate". Beyond Descriptive Translation Studies edited by Anthony Pym et al. Amsterdam: Benjamins: 311-328.

Sarcevic, Susan. 1985. "Translation of culture-bound terms in laws". Multilingua 4, (3):127-133.

Sarcevic, S. (1988). Terminological Incongruency in Legal Dictionaries for Translation. Euralex Proceedings. Retrieved from http://www.euralex.org/elx_proceedings/Euralex1988/057_Susan\%20Sarcevic\%20\%28Rijeka\%29\% 20-20Terminological\%20Incongruency\%20in\%20Legal\%20Dictionaries\%20for\%20Translation.pdf.

Shreve, G.M. 2006. "Corpus enhancement and computer-assisted localization and translation". Perspectives on Localization. Edited by Keiran J. Dunne. Amsterdam/Philadelphia: John Benjamins Publishing Company. 309-331.

Vargas Sierra, Consuelo. 2012. "La tecnología de corpus en el contexto profesional y académico de la traducción y la terminología: panorama actual, recursos y perspectivas". In. Tecnología, 
Traducción y Cultura,edited by Candel-Mora, M.A. and Ortega-Arjonilla, E. Valencia: Editorial Tirant lo Blanc, 67- 99. http://goo.gl/B0wo3B

Weston, Martin. 1991. An English reader's guide to the French legal system. New York \& Oxford: Berg.

\footnotetext{
${ }^{1}$ http://www.linguee.es/

${ }^{2}$ http://www.2lingual.com/

${ }^{3}$ http://diccionario.reverso.net/

${ }^{4}$ http://www.webitext.com/bin/webitext.cgi

${ }^{5}$ https://glosbe.com
}

${ }^{6}$ For further English-Spanish corpus resources, see Vargas, 2012.

${ }^{7}$ Unless otherwise noted all translations are my own.

${ }^{8}$ Within the Law $10 \mathrm{~N}$ research project created a corpus of end user license agreements that can be consulted at the following address: http://lawcalisation.com/

${ }^{9}$ Google The Google search engine, which began in 1998, is today used for approximately 80 per cent of all searches. This example is taken from the conditions of use on this link http://www.google.com/intl/es/policies/terms/ [last accessed, 16/04/2014]. 
${ }^{10}$ Judgement 113/13 of the Madrid Fifth Mercantil Court, 30 September 2013.

${ }^{11}$ Sections 1281 to 1289 of the Spanish Civil Code.

${ }^{12}$ Section 1281 of the Spanish Civil Code.

${ }^{13}$ Sections 14 - 17 of Spanish Law 34/2002, 11 July 2002 on services within the information society and online commerce.

${ }^{14}$ In particular, articles 85 and 89 of Spanish Royal Decree 1/2007, of 16 November, which approves the revised text of the General Law on Consumer Protection and other complementary laws.

${ }^{15}$ In BHPetroleum $v$ British Steel, 1999 and Ferryways NV v Associated British Ports, 2008.

${ }^{16}$ Unfair Terms in Consumer Contracts Regulations, 1999, regulation 7 establishes that a seller or supplier shall ensure that any written term of a contract is expressed in plain, intelligible language"; Spanish legislation, RDL 1/2007, General Law on Consumer Protection, art. 80.1.a) employs the terms corrección, claridad y sencillez en la redacción.

${ }^{17}$ This is the definition that appears in article 2 of Directive $85 / 577$ though, with some slight differences, we can find similar definitions in Directive 90/314, 93/13 and 94/47, among others. 